Prepared in cooperation with the

U.S. Department of Energy,

National Nuclear Security Administration Nevada Site Office,

Office of Environmental Management under Interagency Agreement,

DE-A152-01NV13944

\title{
Database of Ground-Water Levels in the Vicinity of Rainier Mesa, Nevada Test Site, Nye County, Nevada, 1957-2005
}

Data Series 190 



\section{Database of Ground-Water Levels in the Vicinity of Rainier Mesa, Nevada Test Site, Nye County, Nevada, 1957-2005}

By Joseph M. Fenelon

Prepared in cooperation with the

U.S. Department of Energy

National Nuclear Security Administration Nevada Site Office,

Office of Environmental Management under Interagency Agreement, DE-A152-01NV13944

Data Series 190 


\title{
U.S. Department of the Interior \\ Dirk A. Kempthorne, Secretary \\ U.S. Geological Survey \\ P. Patrick Leahy, Acting Director
}

\section{U.S. Geological Survey, Reston, Virginia: 2006}

\author{
For sale by U.S. Geological Survey, Information Services \\ Box 25286, Denver Federal Center \\ Denver, CO 80225 \\ For more information about the USGS and its products: \\ Telephone: 1-888-ASK-USGS \\ World Wide Web: http://www.usgs.gov/
}

\footnotetext{
Any use of trade, product, or firm names in this publication is for descriptive purposes only and does not imply endorsement by the U.S. Government.

Although this report is in the public domain, permission must be secured from the individual copyright owners to reproduce any copyrighted materials contained within this report.

Suggested citation:

Fenelon, J.M., 2006, Database of ground-water levels in the vicinity of Rainier Mesa, Nevada Test Site, Nye County, Nevada, 1957-2005: U.S. Geological Survey Data Series 190, 14 p. Available at URL: http://pubs.water.usgs.gov/ $\underline{\text { ds190 }}$
} 


\section{Contents}

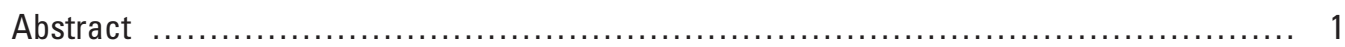

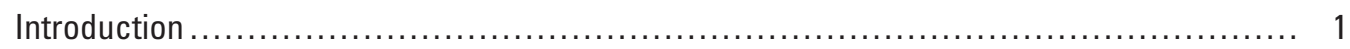

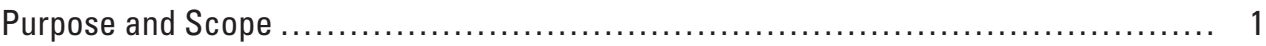

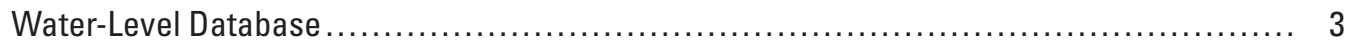

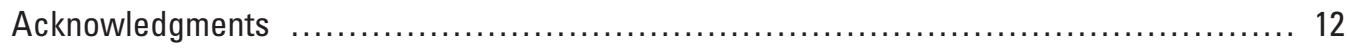

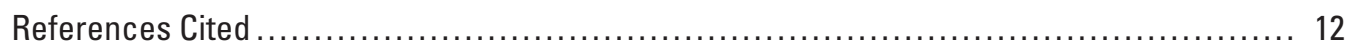

Appendix 1. Water-Level Database for Rainier Mesa and Vicinity, Nevada Test Site,

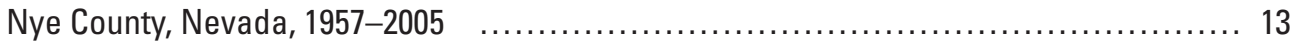

\section{Figures}

Figure 1. Map showing boreholes and tunnel sites with water-level measurements, location of underground nuclear tests, and selected tunnels in the vicinity of Rainier Mesa, Nevada Test Site, Nye County, Nevada ..........................

Figure 2. Diagram showing relations among Microsoft ${ }^{\circledR}$ Access files in water-level database for Rainier Mesa area, Nevada Test Site, Nye County, Nevada .......... 7

Figure 3. Example water-level output from Microsoft ${ }^{\circledR}$ Excel workbook.................. 8

\section{Tables}

Table 1. Characteristics of sites with at least one water-level measurement through 2005 in the Rainier Mesa area, Nevada Test Site, Nye County, Nevada

Table 2. Summary of water-level measurements from sites in the Rainier Mesa area, Nevada Test Site, Nye County, Nevada

Table 3. Description of tables contained in the water-level database for the Rainier Mesa area, Nevada Test Site, Nye County, Nevada

Table 4. Description of general- and detailed-condition attributes assigned to water levels in Rainier Mesa area, Nevada Test Site, Nye County, Nevada 


\section{Conversion Factors and Datums}

\begin{tabular}{lcl}
\hline Multiply & By & To obtain \\
\hline inch (in.) & Length & \\
foot (ft) & 2.54 & centimeter $(\mathrm{cm})$ \\
mile (mi) & 0.3048 & meter $(\mathrm{m})$ \\
& 1.609 & kilometer $(\mathrm{km})$ \\
\hline gallon (gal) & Volume & \\
\hline & 3.785 & liter $(\mathrm{L})$ \\
\hline pound per square inch $(\mathrm{psi})$ & Pressure & \\
\hline & 6.895 & kilopascal $(\mathrm{kPa})$ \\
\hline gallon per minute $(\mathrm{gal} / \mathrm{min})$ & Volumetric Rate & \\
\hline
\end{tabular}

Datums

Horizontal coordinate information is referenced to the North American Datum of 1983 (NAD 83) unless otherwise stated.

Vertical coordinate information is referenced to the National Geodetic Vertical Datum of 1929 (NGVD 29).

Altitude, as used in this report, refers to its distance above the vertical datum.

Transmissivity: The standard unit for transmissivity is cubic foot per day per square foot times foot of aquifer thickness [(ft $\left.\left.\mathrm{ft}^{3} / \mathrm{d}\right) / \mathrm{ft}^{2}\right] \mathrm{ft}$. In this report, the mathematically reduced form, foot squared per day $\left(\mathrm{ft}^{2} / \mathrm{d}\right)$, is used for convenience. 


\title{
Database of Ground-Water Levels in the Vicinity of Rainier Mesa, Nevada Test Site, Nye County, Nevada, 1957-2005
}

\author{
By Joseph M. Fenelon
}

\section{Abstract}

More than 1,200 water-level measurements from 1957 to 2005 in the Rainier Mesa area of the Nevada Test Site were quality assured and analyzed. Water levels were measured from 50 discrete intervals within 18 boreholes and from 4 tunnel sites. An interpretive database was constructed that describes water-level conditions for each water level measured in the Rainier Mesa area. Multiple attributes were assigned to each water-level measurement in the database to describe the hydrologic conditions at the time of measurement. General quality, temporal variability, regional significance, and hydrologic conditions are attributed for each waterlevel measurement. The database also includes hydrograph narratives that describe the water-level history of each well.

\section{Introduction}

Rainier Mesa is in the north-central part of the Nevada Test Site (NTS) in Nye County, southern Nevada (fig. 1). During 1957-92, 16 tunnels were mined in the Rainier Mesa area (U.S. Department of Energy, 2006). The five largest of these tunnel complexes (tunnels U-12b, U-12e, U-12g, U- 12n, and $U-12 t$ ) are shown in figure 1 . Sixty nuclear devices were detonated in the tunnels and two nuclear devices were detonated in vertical shafts in the Rainier Mesa area (U.S. Department of Energy, 2000).

The U.S. Department of Energy (DOE), National Nuclear Security Administration Nevada Site Office, under its Environmental Restoration Program, has a long-term program to investigate and remediate radionuclide contaminants generated on the NTS as a result of nuclear testing. As part of the program, DOE is evaluating what risk these contaminants may pose to the public. To help accomplish this objective, ground-water levels are being compiled and analyzed to better understand the ground-water flow system. This report is the fourth in a series of studies by the U.S. Geological Survey (USGS), in cooperation with DOE, to analyze and quality assure historic water-level measurements in areas of testing on the NTS (Fenelon, 2000; Bright and others, 2001; Fenelon, 2005).
Rainier Mesa is a volcanic plateau at an altitude of about 7,500 ft above sea level. It receives about $12.5 \mathrm{in}$. of precipitation annually (Air Resources Laboratory, Special Operations and Research Division, 2005). About 2,000 to $5,000 \mathrm{ft}$ of Tertiary volcanic rocks, consisting primarily of bedded and welded tuffs, underlie Rainier Mesa (Thordarson, 1966, p. 14). The lower units consist of low-permeability bedded tuffs that impede the downward flow of recharge water from the overlying fractured welded tuffs, creating a perched ground-water system in the volcanic rocks (Thordarson, 1966, p. 32-33). The water-level altitude in the perched system is irregular but generally ranges from about 5,700 to 6,200 $\mathrm{ft}$ above sea level. Beneath the volcanic rocks on Rainier Mesa are Paleozoic carbonate rocks, Mesozoic granites, and Paleozoic and Precambrian quartzite and argillite. A regional water table is found in the Paleozoic carbonate rocks at an altitude from about 4,200 to 4,300 ft above sea level and at depths ranging from about $1,400 \mathrm{ft}$ off of the mesa to as great as $3,100 \mathrm{ft}$ on top of the mesa.

\section{Purpose and Scope}

This report documents and describes more than 1,200 water-level measurements made in the Rainier Mesa area from 1957 to 2005. Water levels were measured from 50 discrete intervals within 18 boreholes and from 4 tunnel sites. As part of the analysis, a systematic quality-assurance review of the USGS National Water Information System (NWIS) database was completed to remove or correct erroneous water-level data, and to add missing water-level measurements and well-site information. Well-completion data and boreholelithologic descriptions were compiled from driller's logs, well completion reports, and other published and unpublished information.

An interpretive Microsoft $₫$ Access database of Rainier Mesa water-level measurements was constructed that consists of several components. First, each water-level measurement was assigned multiple attributes to describe the hydrologic condition at the time of measurement. Second, each well hydrograph has a written narrative, which consists of information and comments about the well and water-level data for the well. Third, water-level data and site information from the NWIS database were merged into the water-level database to provide supporting information for use in interpreting water-level measurements in the vicinity of Rainier Mesa. 

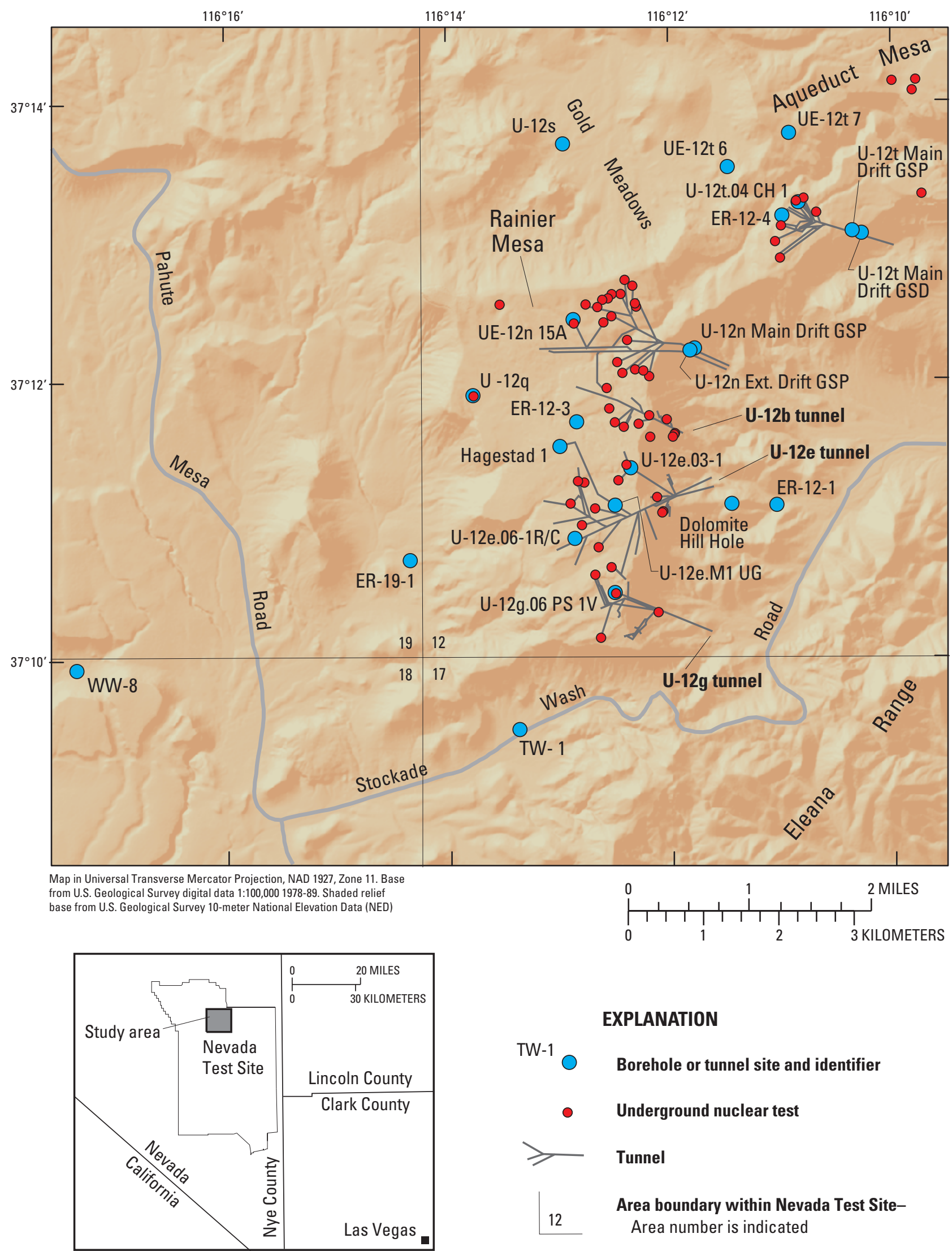

Figure 1. Boreholes and tunnel sites with water-level measurements, location of underground nuclear tests, and selected tunnels in the vicinity of Rainier Mesa, Nevada Test Site, Nye County, Nevada. 


\section{Water-Level Database}

The USGS collects and maintains water-level data for sites at the Nevada Test Site. As part of this data-collection program, current and historic water-level data are compiled, reviewed, and stored in the USGS NWIS database (http:// waterdata.usgs.gov/nv/nwis/nwis). For the Rainier Mesa area, the database contains about 1,000 water-level measurements from 50 discrete intervals within 18 boreholes. Additionally, about 200 water-level measurements of impounded tunnel water at four tunnel sites in Rainier Mesa (Charles Russell and others, Desert Research Institute, written commun., 2003) were compiled for this report but are not in the NWIS database. Water-level data for the 54 measurement sites (fig. 1, table 1) were collected periodically from 1957 to 2005 .

Table 1. Characteristics of sites with at least one water-level measurement through 2005 in the Rainier Mesa area, Nevada Test Site, Nye County, Nevada.

[Latitude and Longitude: In decimal degrees; referenced to North American Datum of 1983 (NAD83). Land-surface altitude: Altitude relative to sea level Open interval: Area of well that is open to aquifer and where, if saturated, ground water may enter well. Open interval consists of open borehole and (or) well screen, including gravel packs. Where multiple open intervals occur in a well, depths are in feet below land surface to top of uppermost interval and bottom of lowermost interval. Contributing units: Lithologic units contributing water to well. Multiple units for single well listed in order of their likely importance in contributing water to well. C, Paleozoic carbonate rock; P, Paleocolluvium; S, pre-Tertiary clastic rock; V, volcanic rocks (primary tuffs); X, igneous or metamorphic rocks; *, hole was dry and contributing unit listed is the unit at bottom of hole; queried (?) where uncertain]

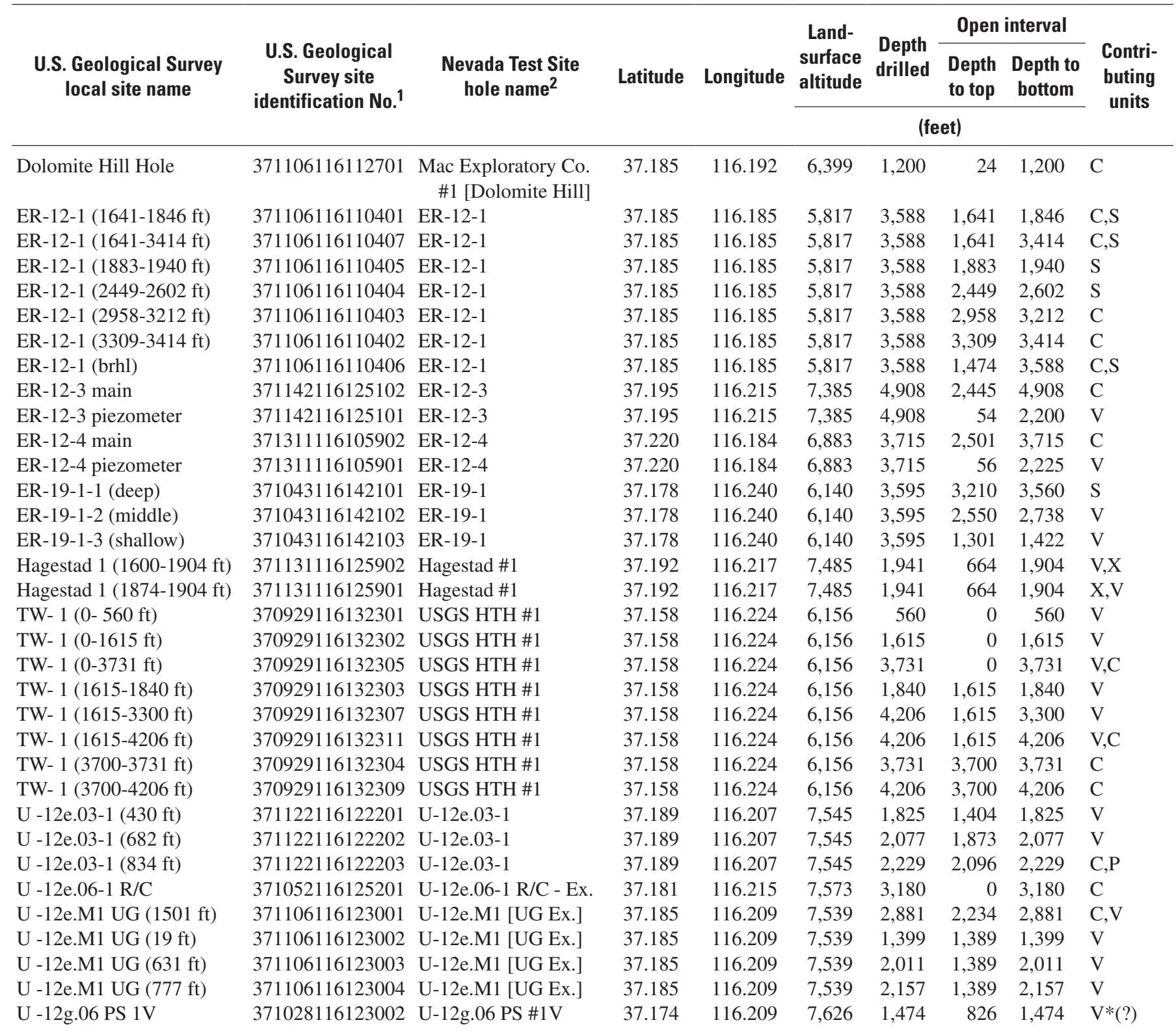


Table 1. Characteristics of sites with at least one water-level measurement through 2005 in the Rainier Mesa area, Nevada Test Site, Nye County, Nevada.-Continued

[Latitude and Longitude: In decimal degrees; referenced to North American Datum of 1983 (NAD83). Land-surface altitude: Altitude relative to sea level. Open interval: Area of well that is open to aquifer and where, if saturated, ground water may enter well. Open interval consists of open borehole and (or) well screen, including gravel packs. Where multiple open intervals occur in a well, depths are in feet below land surface to top of uppermost interval and bottom of lowermost interval. Contributing units: Lithologic units contributing water to well. Multiple units for single well listed in order of their likely importance in contributing water to well. C, Paleozoic carbonate rock; P, Paleocolluvium; S, pre-Tertiary clastic rock; V, volcanic rocks (primary tuffs); X, igneous or metamorphic rocks; *, hole was dry and contributing unit listed is the unit at bottom of hole; queried (?) where uncertain]

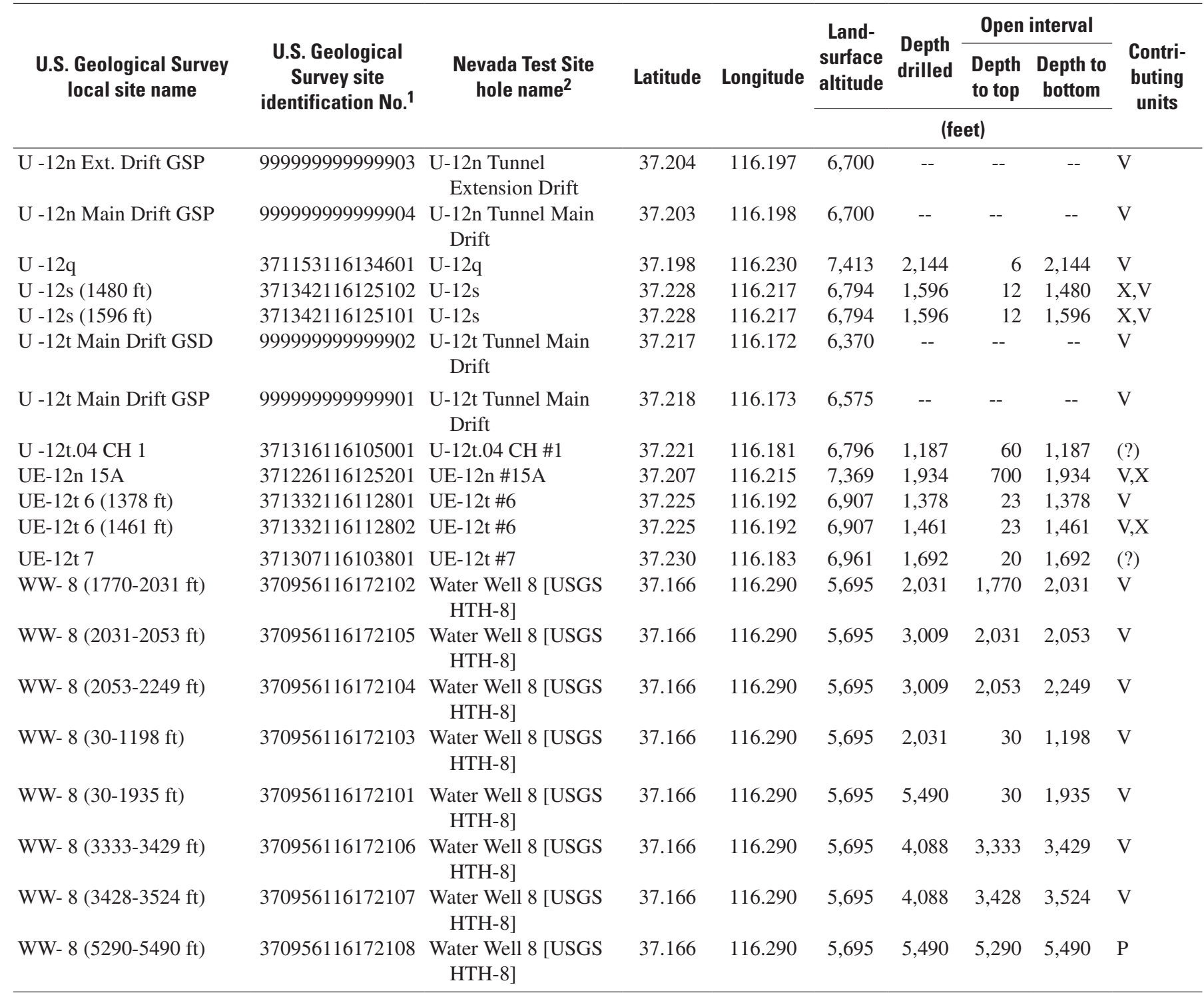

\footnotetext{
${ }^{1}$ The U.S. Geological Survey site identification is based on the latitude-longitude grid. Each site is identified by a unique 15-digit number. The first six digits denote degrees, minutes, and seconds of latitude; the next seven digits denote degrees, minutes, and seconds of longitude; and the last two digits are the sequence number of the well or test hole within the 1-second grid of latitude and longitude. The assigned number is retained as a permanent identifier even if a more precise latitude and longitude are later determined. To determine the geographic location of a well or test hole, the latitude and longitude coordinates should be used rather than the site identifier. Site identifications beginning with "99" are used in this report only and are not in the National Water Information System (NWIS).

${ }^{2}$ Official Nevada Test Site (NTS) hole names are assigned to test holes according to the type of hole drilled, site location (NTS area number), and sequence code for consecutive order in which the hole was drilled or redrilled. Most of the holes drilled on the NTS begin with the letter "U." Exploratory holes, drilled to assess material properties within a defined area, are designated with an "E" following the "U." The "U" or "UE" are followed by a dash (-), NTS area number, and sequence code (letters "a-z, aa-az, ba-bz, ..., za-zz"). The suffix "PS" indicates a postshot hole, the suffix "\#” followed by a number indicates a satellite hole, and "HTH" indicates a hydrologic test hole. Exceptions to the standard naming convention are wells beginning with "ER," which indicates a well drilled for the Environmental Restoration Program.
} 
Water-level data contained in the database and in this report were collected from multi-screen completion wells, from wells or boreholes with packers temporarily installed during or after drilling, and from open boreholes that may later have been deepened or completed into a well. In these situations, a unique site identification number and site name were established in the database for each discrete open interval where data were collected. In other situations, multiple piezometers, open at different intervals, were placed in a single borehole. In these cases, each piezometer is considered a site in the database. Site names from the same borehole are distinguished from each other by a parenthetical expression following the borehole name-for example: UE-12t 6 $(1378 \mathrm{ft})$. A single number in the parenthetical expression refers to the depth of the well or borehole; two numbers separated by a dash refer to the depth of the top and bottom of the open interval in the well or borehole. For the purposes of this report, a discrete open interval where water levels were monitored may be referred to as a well or a site.

Periodic water-level measurements were made by the USGS or private contractors working at the NTS using calibrated electric-cable units (also known as iron-horse and wire-line devices), calibrated electric tapes, and less commonly, a fluid-density geophysical log, float recorder, pressure gauge, or pressure transducer. Most water-level measurements prior to 1996 were made with an electric-cable unit (Garber and Koopman, 1968); whereas, more recent measurements typically were made using electric tapes. The tapes and cable units are calibrated annually at different waterlevel depths with a USGS 2,000-ft steel reference tape. At the time of measurement, a correction factor is applied to the depth-to-water reading based on the annual calibration. Recent (post-1995) measurements using electric tapes generally are more accurate $( \pm 0.1 \mathrm{ft})$ than older measurements using electric-cable units or other methods $( \pm 0.5-1 \mathrm{ft})$.

A systematic quality-assurance review of data contained in the NWIS database from 1957 to 2005 for sites in the Rainier Mesa area was completed for this study. This included removing or correcting duplicate sites or erroneous waterlevel data, and adding missing water-level measurements and construction information. A summary of water-level measurements from the 54 sites is shown in table 2. The earliest measurement was made in 1957 and 11 sites were measured in 2005. The deepest measured depth to water was 3,116 ft in well ER-12-3 main (fig. 1).

Table 2. Summary of water-level measurements from sites in the Rainier Mesa area, Nevada Test Site, Nye County, Nevada.

[Number of measurements: Includes measurements indicating well was dry or obstructed. Minimum and maximum water level: -, a measurement of the water surface was not made in the well because the well was dry or obstructed]

\begin{tabular}{|c|c|c|c|c|}
\hline \multirow{3}{*}{$\begin{array}{l}\text { U.S. Geological Survey } \\
\text { local site name }\end{array}$} & \multicolumn{4}{|c|}{ Water level } \\
\hline & \multirow{2}{*}{ Period of record } & \multirow{2}{*}{$\begin{array}{c}\text { Number of } \\
\text { measurements }\end{array}$} & $\begin{array}{l}\text { Minimum } \\
\text { (shallowest) }\end{array}$ & $\begin{array}{c}\text { Maximum } \\
\text { (deepest) }\end{array}$ \\
\hline & & & \multicolumn{2}{|c|}{ (feet below land surface) } \\
\hline Dolomite Hill Hole & 1959-1960 & 11 & 1,110 & 1,130 \\
\hline ER-12-1 (1641-1846ft) & 1992-2005 & 90 & 1,450 & 1,542 \\
\hline ER-12-1 (1641-3414ft) & 1992 & 3 & 1,536 & 1,546 \\
\hline ER-12-1 (1883-1940 ft) & 1992 & 1 & 1,480 & 1,480 \\
\hline ER-12-1 (2449-2602 ft) & 1992 & 1 & 1,434 & 1,434 \\
\hline ER-12-1 (2958-3212ft) & 1992 & 1 & 2,779 & 2,779 \\
\hline ER-12-1 (3309-3414ft) & 1992 & 1 & 2,762 & 2,762 \\
\hline ER-12-1 (brhl) & 1991 & 6 & 1,538 & 1,546 \\
\hline ER-12-3 main & 2005 & 8 & 3,112 & 3,116 \\
\hline ER-12-3 piezometer & 2005 & 9 & 1,245 & 1,250 \\
\hline ER-12-4 main & 2005 & 9 & 2,566 & 2,654 \\
\hline ER-12-4 piezometer & 2005 & 4 & 916 & 917 \\
\hline ER-19-1-1 (deep) & 1994-2005 & 50 & 1,776 & 1,794 \\
\hline ER-19-1-2 (middle) & 1994-2005 & 51 & 1,142 & 1,321 \\
\hline ER-19-1-3 (shallow) & $1994-2005$ & 60 & 1,005 & 1,008 \\
\hline Hagestad 1 (1600-1904 ft) & $1958-1963$ & 52 & 1,436 & 1,573 \\
\hline Hagestad 1 (1874-1904 ft) & $1957-1958$ & 14 & 1,359 & 1,930 \\
\hline TW- $1(0-560 \mathrm{ft})$ & 1960 & 1 & 410 & 410 \\
\hline TW- 1 (0-1615 ft) & 1960 & 2 & 415 & 416 \\
\hline TW- 1 (0-3731 ft) & $1961-1962$ & 4 & 1,026 & 1,032 \\
\hline
\end{tabular}


Table 2. Summary of water-level measurements from sites in the Rainier Mesa area, Nevada Test Site, Nye County, Nevada.-Continued.

[Number of measurements: Includes measurements indicating well was dry or obstructed. Minimum and maximum water level: -, a measurement of the water surface was not made in the well because the well was dry or obstructed]

\begin{tabular}{|c|c|c|c|c|}
\hline \multirow{3}{*}{$\begin{array}{l}\text { U.S. Geological Survey } \\
\text { local site name }\end{array}$} & \multicolumn{4}{|c|}{ Water level } \\
\hline & \multirow{2}{*}{ Period of record } & \multirow{2}{*}{$\begin{array}{c}\text { Number of } \\
\text { measurements }\end{array}$} & $\begin{array}{c}\text { Minimum } \\
\text { (shallowest) }\end{array}$ & $\begin{array}{c}\text { Maximum } \\
\text { (deepest) }\end{array}$ \\
\hline & & & \multicolumn{2}{|c|}{ (feet below land surface) } \\
\hline TW- 1 (1615-1840 ft) & 1961 & 2 & 1,023 & 1,024 \\
\hline TW- 1 (1615-3300 ft) & $1962-1963$ & 16 & 1,439 & 1,441 \\
\hline TW- 1 (1615-4206 ft) & 1965-2005 & 112 & 1,461 & 2,081 \\
\hline TW- $1(3700-3731 \mathrm{ft})$ & 1961 & 1 & 1,984 & 1,984 \\
\hline TW- 1 (3700-4206 ft) & $1962-1963$ & 16 & 1,965 & 1,969 \\
\hline $\mathrm{U}-12 \mathrm{e} .03-1(430 \mathrm{ft})$ & 1959 & 1 & 1,378 & 1,378 \\
\hline $\mathrm{U}-12 \mathrm{e} .03-1(682 \mathrm{ft})$ & 1959 & 1 & 1,879 & 1,879 \\
\hline $\mathrm{U}-12 \mathrm{e} .03-1(834 \mathrm{ft})$ & 1959 & 1 & 2,105 & 2,105 \\
\hline $\mathrm{U}-12 \mathrm{e} .06-1 \mathrm{R} / \mathrm{C}$ & 1962-1976 & 5 & 2,920 & 2,931 \\
\hline U -12e.M1 UG (1501ft) & 1960 & 3 & 2,832 & 2,865 \\
\hline U -12e.M1 UG (19ft) & 1959 & 1 & 1,379 & 1,379 \\
\hline U -12e.M1 UG (631ft) & 1959 & 1 & 1,354 & 1,354 \\
\hline U -12e.M1 UG (777ft) & 1959 & 1 & 1,434 & 1,434 \\
\hline $\mathrm{U}-12 \mathrm{~g} .06 \mathrm{PS} 1 \mathrm{~V}$ & 1980 & 1 & - & - \\
\hline U -12n Ext. Drift GSP & 1994-2002 & 21 & 602 & 641 \\
\hline U -12n Main Drift GSP & 1994-2002 & 23 & 603 & 643 \\
\hline$U-12 q$ & 1962 & 3 & 1,814 & 1,831 \\
\hline $\mathrm{U}-12 \mathrm{~s}(1480 \mathrm{ft})$ & 1966-2005 & 396 & 910 & 958 \\
\hline $\mathrm{U}-12 \mathrm{~s}(1596 \mathrm{ft})$ & 1966 & 3 & 966 & 1,104 \\
\hline U -12t Main Drift GSD & 1993-2002 & 32 & 992 & 1,088 \\
\hline U -12t Main Drift GSP & 1993-2002 & 116 & 1,062 & 1,089 \\
\hline $\mathrm{U}-12 \mathrm{t} .04 \mathrm{CH} 1$ & 1982 & 3 & 875 & 884 \\
\hline UE-12n 15A & 1988 & 5 & 1,326 & 1,331 \\
\hline UE-12t 6 (1378 ft) & 1988 & 3 & 814 & 867 \\
\hline UE-12t 6 (1461 ft) & 1988-2005 & 82 & 70 & 847 \\
\hline UE-12t 7 & 1988-1989 & 28 & 496 & 840 \\
\hline WW- 8 (1770-2031 ft) & 1962 & 20 & 1,055 & 1,070 \\
\hline WW- $8(2031-2053 \mathrm{ft})$ & 1962 & 54 & 1,017 & 1,316 \\
\hline WW- $8(2053-2249 \mathrm{ft})$ & 1962 & 72 & 677 & 1,148 \\
\hline WW- $8(30-1198 \mathrm{ft})$ & 1962 & 57 & 997 & 1,070 \\
\hline WW- 8 (30-1935 ft) & 1963-2000 & 11 & 1,068 & 1,083 \\
\hline WW- $8(3333-3429 \mathrm{ft})$ & 1962 & 25 & 1,062 & 1,098 \\
\hline WW- $8(3428-3524 \mathrm{ft})$ & 1962 & 47 & 1,057 & 1,308 \\
\hline WW- $8(5290-5490 \mathrm{ft})$ & 1962 & 37 & 1,101 & 1,434 \\
\hline
\end{tabular}


An interpretive database using Microsoft ${ }^{\circledR}$ Access format was constructed that provides information on the external conditions influencing each water level measured in the Rainier Mesa area. The database contains site information for each well, well-construction records, borehole lithology, aquifer data, and water-level data (appendix 1). Information in this database was derived from data sets created for this study and data sets available from NWIS. All tables are linked by the USGS local site name and site identification number, a unique 15-digit number used to identify the site (table 1). Several of the tables also are linked by water-level date. The structure of the water-level database is shown in figure 2. An effort was made to maintain a database structure that is consistent with the structure of the NWIS database (U.S. Geological Survey,
2004). For example, the four well-construction tables from NWIS are preserved in the water-level database.

Hydrographs and site locations in Rainier Mesa are interactively presented with a Microsoft $®$ Excel workbook. The workbook is designed to be an easy-to-use tool to understand the water-level history for any site in the Rainier Mesa area. It also can be used to filter water-level data by restricting the data to certain sites, dates, or hydrologic conditions.

An example page from the workbook (fig. 3) shows well UE-12t 6 (1378 ft), which was selected using the Excel builtin AutoFilter. Selected water-level information from the waterlevel database is shown for this well. Additionally, a short narrative is displayed that describes the well and hydrograph.

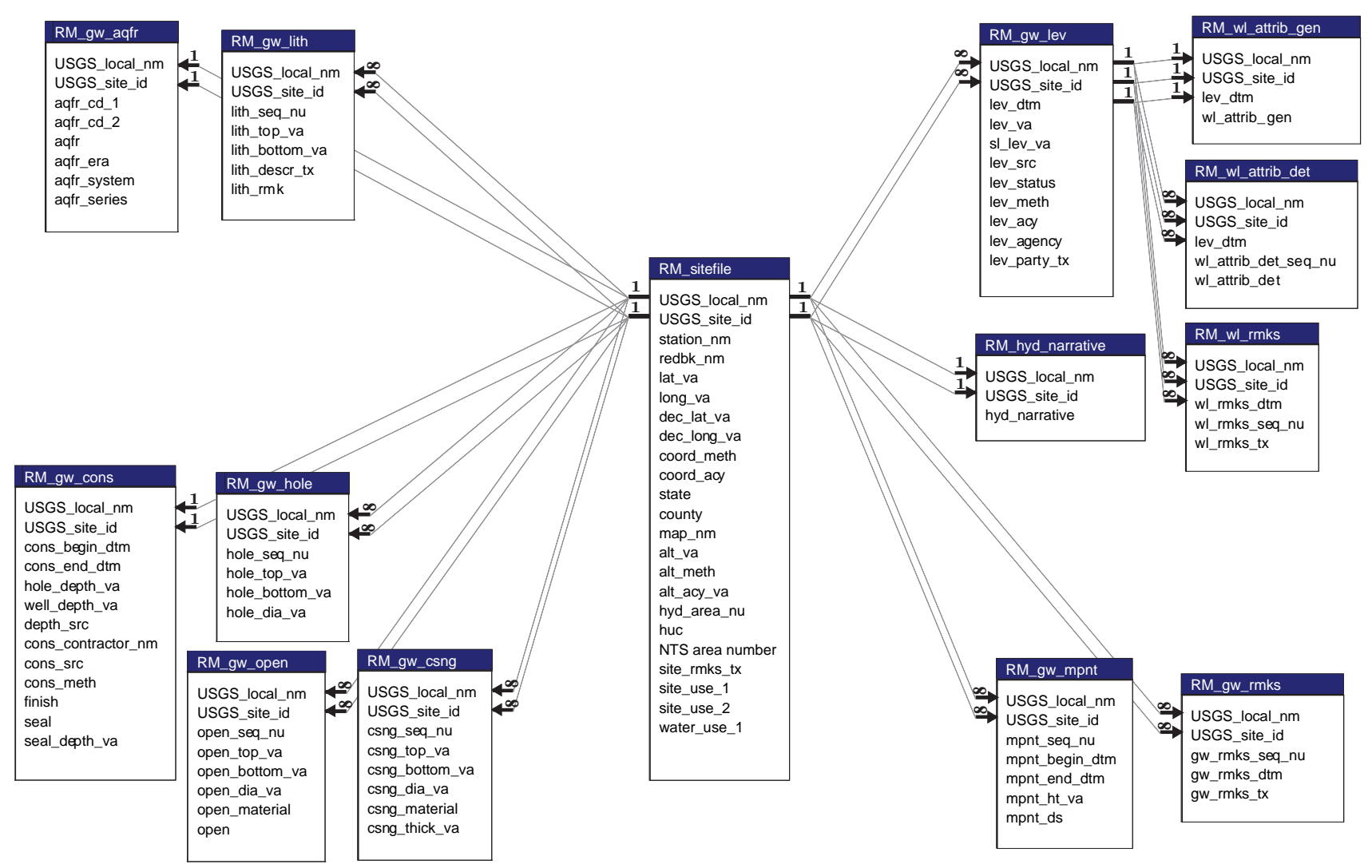

Figure 2. Relations among Microsoft@ Access files in water-level database for Rainier Mesa area, Nevada Test Site, Nye County, Nevada. 


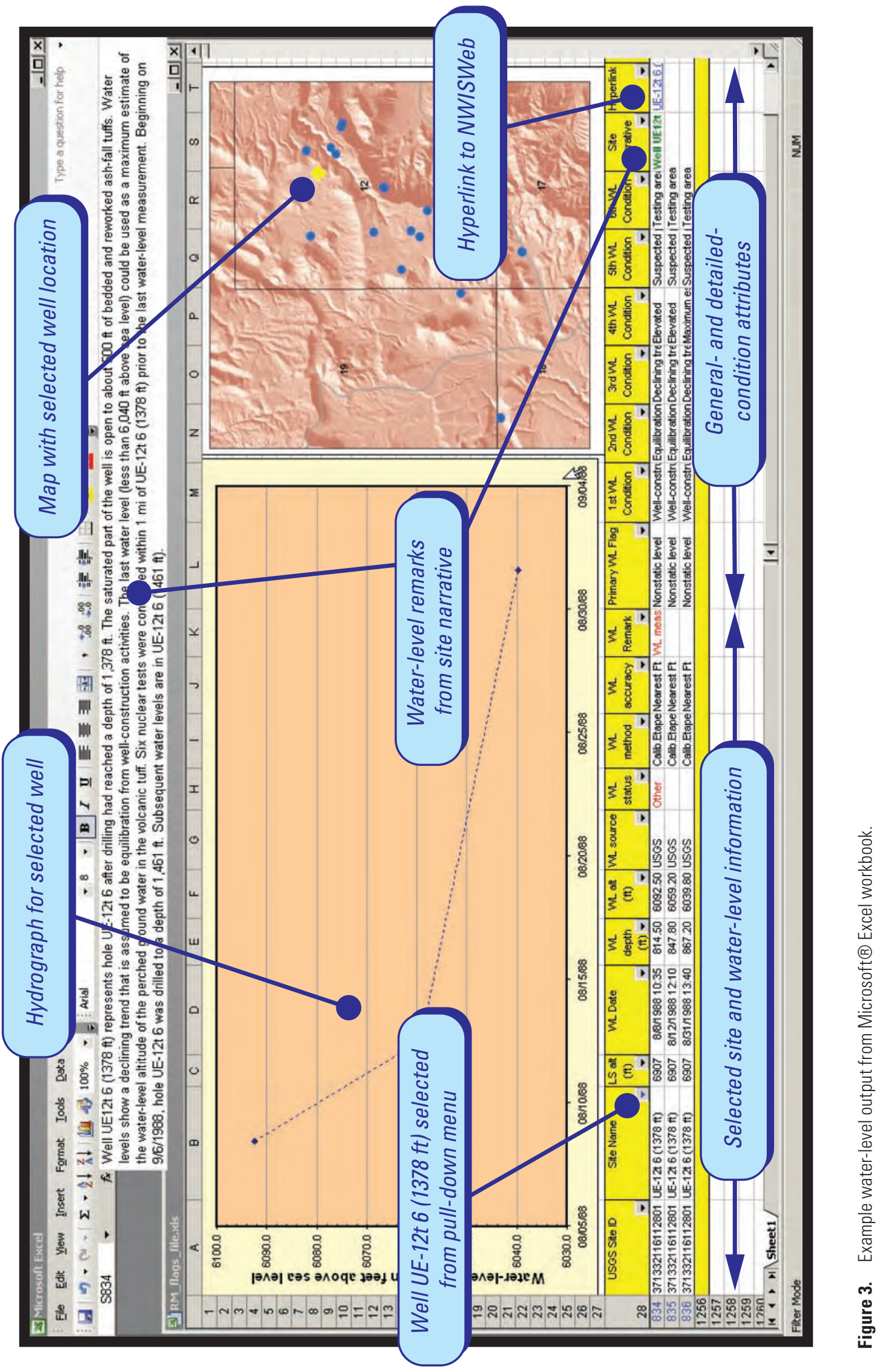


Site, well-construction, and lithology information for the 54 Rainier Mesa water-level sites are stored in the waterlevel database (appendix 1). This information, which can be used to support interpretations of the water levels and waterlevel trends, is contained within nine tables in the water-level database (table 3). Five additional tables in the database provide water-level information, including water-level data, hydrologic conditions of each water-level measurement, and a water-level history for each site (table 3).

Table 3. Description of tables contained in the water-level database for the Rainier Mesa area, Nevada Test Site, Nye County, Nevada.

\begin{tabular}{|c|c|c|c|}
\hline Table name & Table grouping & Description & Remarks \\
\hline RM_gw_rmks & Site information & $\begin{array}{l}\text { Miscellaneous remarks related } \\
\text { to the site, well, or water-level } \\
\text { data. }\end{array}$ & $\begin{array}{l}\text { Remarks derived from a variety of sources including published } \\
\text { reports, drilling records, or field notes. }\end{array}$ \\
\hline RM_gw_cons & $\begin{array}{l}\text { Well-construction } \\
\text { information }\end{array}$ & $\begin{array}{l}\text { Construction dates, hole and well } \\
\text { depth, and construction method. }\end{array}$ & General construction information. \\
\hline RM_gw_csng & $\begin{array}{l}\text { Well-construction } \\
\text { information }\end{array}$ & Casing diameters and intervals. & $\begin{array}{l}\text { May have multiple entries for each site that describe unique } \\
\text { intervals of casing. }\end{array}$ \\
\hline RM_gw_open & $\begin{array}{l}\text { Well-construction } \\
\text { information }\end{array}$ & Open-interval information. & $\begin{array}{l}\text { May have multiple entries for each site, each describing a } \\
\text { unique open interval. Open-intervals are defined by the } \\
\text { diameter of the interval, the depths to the top and bottom } \\
\text { of the interval, and the type of interval. The most common } \\
\text { interval types are well screen and open hole. A typical site } \\
\text { may have two open-interval entries in the database. One } \\
\text { describes the screen or slotted interval and the other describes } \\
\text { the open hole that surrounds the screen. The open-hole } \\
\text { interval, which is commonly longer than and inclusive of the } \\
\text { screened interval, may be sand or gravel packed or may be } \\
\text { unfilled. }\end{array}$ \\
\hline RM_gw_lev & $\begin{array}{l}\text { Water-level } \\
\text { information }\end{array}$ & $\begin{array}{l}\text { Date, depth, source, status, } \\
\text { method, and accuracy of water } \\
\text { level. }\end{array}$ & $\begin{array}{l}\text { Basic data pertaining to the water-level measurement. Water- } \\
\text { level accuracy pertains to the depth-to-water measurement } \\
\text { and not the water-level altitude. }\end{array}$ \\
\hline RM_wl_rmks & $\begin{array}{l}\text { Water-level } \\
\text { information }\end{array}$ & $\begin{array}{l}\text { Remarks related to specific } \\
\text { water-level measurements. }\end{array}$ & \\
\hline RM_wl_attrib_gen & $\begin{array}{l}\text { Water-level } \\
\text { information }\end{array}$ & $\begin{array}{l}\text { General-condition attribute for } \\
\text { each water level. }\end{array}$ & \\
\hline RM_wl_attrib_det & $\begin{array}{l}\text { Water-level } \\
\text { information }\end{array}$ & $\begin{array}{l}\text { Detailed-condition attributes for } \\
\text { each water level. }\end{array}$ & \\
\hline RM_hyd_narrative & $\begin{array}{l}\text { Water-level } \\
\text { information }\end{array}$ & Hydrograph narrative. & \\
\hline
\end{tabular}


Water-level measurement source, method, accuracy, and hydrologic conditions at the time of the water-level measurement are attributed in the water-level database. Interpretations for individual water-level measurements and for the period of record for a site have been incorporated into the attributes. Abrupt water-level changes and longterm water-level declines are examples of typical hydrologic conditions that were interpreted. These interpretations are noted in the water-level remark, detailed hydrologic condition, or hydrograph narrative.

Hydrologic-condition attributes were used to describe the state of each water level that was measured at sites in the Rainier Mesa area. They also describe the external factors that may have affected the measured depths-to-water at each site. Hydrologic-condition attributes were categorized as either general or detailed (table 4). General-condition attributes describe the state of a water level. Examples are steady state, transient, and nonstatic level. Detailed-condition attributes can denote a factor affecting a water level, describe the effect that a factor may have on a water level, or denote the uncertainty of a water-level interpretation. Factors affecting water levels include perched water, pumping, and recent well construction. Water-level effects include abrupt change, equilibration, and rising trend. One general-condition attribute and 0-6 detailed-condition attributes were assigned to each water-level measurement in the Rainier Mesa area.

The water-level history of each site is documented as a narrative. The narrative consists of comments or explanations about the site or about water-level data at the site. An interpretation of the hydrograph and its hydrologic significance is provided for most sites as part of the narrative. The narrative may include information about the open interval, testing done in the well, the well productivity, specific influences near the site that may have affected water levels, and other details that may provide additional information about the conditions affecting water-level data at the site. Basic information included in the narrative was derived from published reports or from USGS data files stored in Henderson, Nev.

Table 4. Description of general- and detailed-condition attributes assigned to water levels in Rainier Mesa area, Nevada Test Site, Nye County, Nevada.

[Number of water levels: Number of water levels in Rainier Mesa assigned with this attribute. Each water level was assigned only one general-condition attribute but may have multiple detailed-condition attributes]

\begin{tabular}{llc}
\hline Attribute name & $\begin{array}{c}\text { Nescription } \\
\text { of water } \\
\text { levels }\end{array}$
\end{tabular}

General-condition attribute

Localized conditions

None

Nonstatic level

Steady state-LOCAL

Steady state-REGIONAL

Suspect

Transient-LOCAL

Transient-REGIONAL
Water level represents localized, typically transient, hydrologic conditions in aquifer (for example, nuclear-test effect or localized pumping).

Well is dry or obstructed or site was visited but water level was not measured.

Water level is affected by activities in the well such as aquifer testing, well construction, or pumping; water level does not represent conditions within the aquifer.

Water level approximates predevelopment, steady-state, hydrologic conditions in a well that monitors a local-scale flow system, such as a perched aquifer. Water level is considered to be steady state relative to long-term (50-100 years) climatic conditions. Water-level changes occurring as a result of natural conditions are considered steady state for the purposes of this analysis.

Water level approximates predevelopment, steady-state hydrologic conditions in a well that monitors the regional ground-water flow system. The regional flow system is defined as the fully saturated part of the flow system. Water level is considered to be steady state relative to long-term (50-100 years) climatic conditions. Water-level changes occurring as a result of natural conditions are considered steady state for the purposes of this analysis.

Water level is suspect or in error, and cannot be attributed to any known hydrologic cause.

Water level represents changes from pumping in a local-scale flow system, such as a perched aquifer.

Water level represents changes from pumping in the regional ground-water flow system. The regional flow system is defined as the fully saturated part of the flow system.
3 
Table 4. Description of general- and detailed-condition attributes assigned to water levels in Rainier Mesa area, Nevada Test Site, Nye County, Nevada.-Continued.

[Number of water levels: Number of water levels in Rainier Mesa assigned with this attribute. Each water level was assigned only one general-condition attribute but may have multiple detailed-condition attributes]

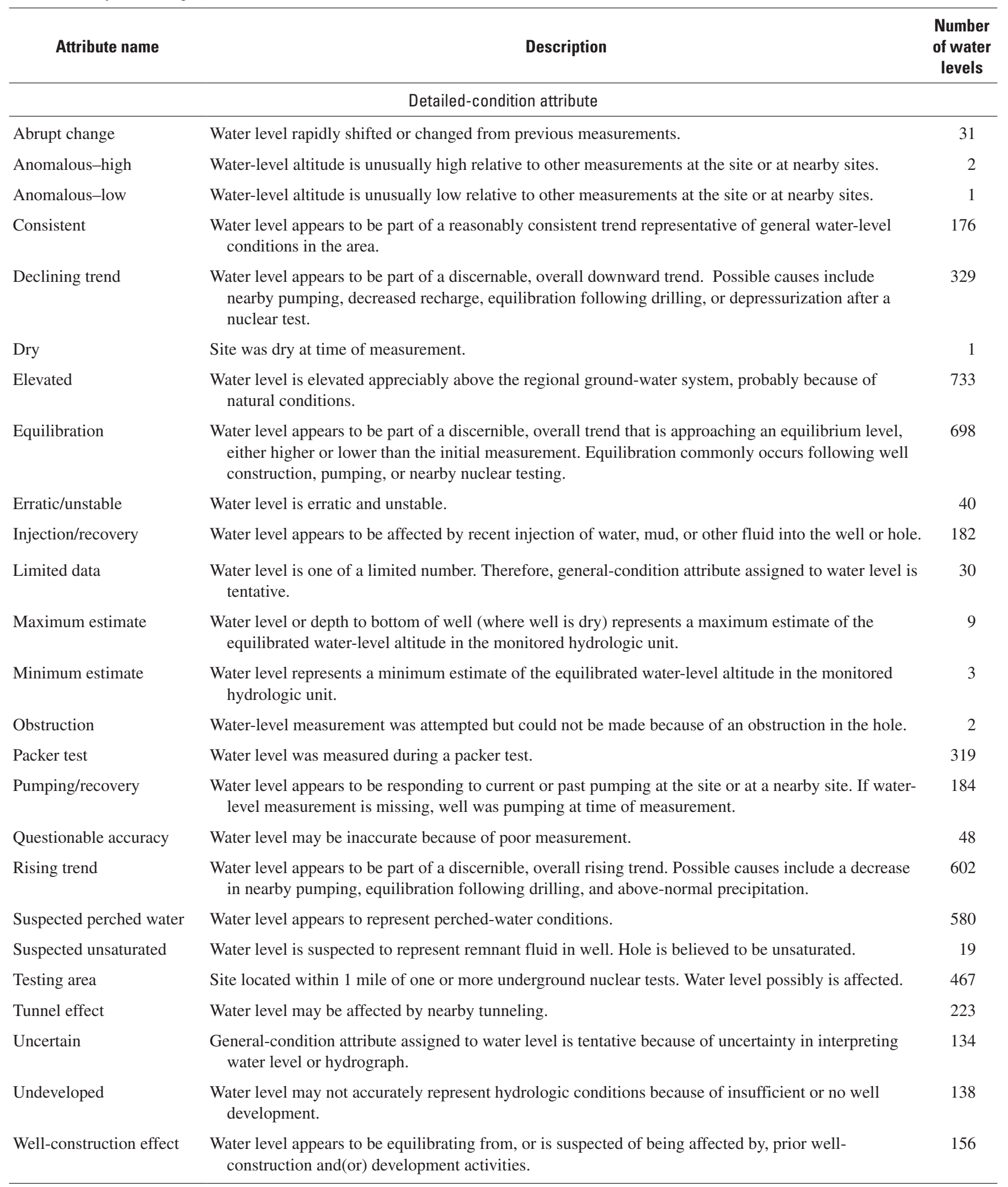




\section{Acknowledgments}

This study was prepared in cooperation with the U.S. Department of Energy under Interagency Agreement DE-AI52-01NV13944. Thanks to David Wood (USGS) and coworkers for electronically compiling most of the borehole lithologic descriptions that are provided in the water-level database (appendix 1). Thanks also to Randell Laczniak (USGS) for general guidance in the interpretation of data.

\section{References Cited}

Air Resources Laboratory, Special Operations and Research Division, 2005, Nevada Test Site (NTS) climatological rain gauge data: National Oceanic and Atmospheric Administration, accessed May 2005 at URL: $<$ http://www. sord.nv.doe.gov/home climate rain.htm>.

Bright, D.J., Watkins, S.A., and Lisle, B.A., 2001, Analysis of water levels in the Frenchman Flat area, Nevada Test Site: U.S. Geological Survey Water-Resources Investigations Report 00-4272, 43 p.

Fenelon, J.M., 2000, Quality assurance and analysis of water levels in wells on Pahute Mesa and vicinity, Nevada Test Site, Nye County, Nevada: U.S. Geological Survey WaterResources Investigations Report 00-4014, 68 p.

Fenelon, J.M., 2005, Analysis of ground-water levels and associated trends in Yucca Flat, Nevada Test Site, Nye County, Nevada, 1951-2003: U.S. Geological Survey Scientific Investigations Report 2005-5175, 87 p.

Garber, M.S., and Koopman, F.C., 1968, Methods of measuring water levels in deep wells: U.S. Geological Survey Techniques of Water-Resources Investigations, chap. A1, book 8, 23 p.
Laczniak, R.J., Cole, J.C., Sawyer, D.A., and Trudeau, D.A., 1996, Summary of hydrogeologic controls on ground-water flow at the Nevada Test Site, Nye County, Nevada: U.S. Geological Survey Water-Resources Investigations Report 96-4109, 59 p.

Rehfeldt, K., Drici, W., Lester, B., Sloop, D., Watrus, J., Beard, T., Sully, M., Fryer, W., and Benedict, C., 2004, Hydrologic data for the groundwater flow and contaminant transport model of Corrective Action Units 101 and 102central and western Pahute Mesa, Nye County, Nevada: Stoller-Navarro Joint Venture Report S-N/99205-002, Shaw/13052-204, Revision No. 0, 422 p.

Russell, C.E., Gillespie, David, Cole, J.C., Drellack, S.L., Prothro, L.B., Thompson, P.H., McCall, R.L., Pawloski, G.A., and Carlson, Richard, 1996, ER-12-1 completion report: Desert Research Institute Publication No. 45120, $158 \mathrm{p}$.

Schoff, S.L., and Winograd, I.J., 1961, Hydrologic significance of six core holes in carbonate rocks of the Nevada Test Site: U.S. Geological Survey Open-File Report 61-152, 97 p.

Thordarson, William, 1966, Perched ground water in zeolitized-bedded tuff, Rainier Mesa and vicinity, Nevada Test Site, Nevada: U.S. Geological Survey Open-File Report 66-130, $90 \mathrm{p}$.

U.S. Department of Energy, 2000, United States nuclear tests, July 1945 through September 1992: U.S. Department of Energy, Nevada Operation Office, DOE/NV-209 (Rev. 15), 162 p.

U.S. Department of Energy, 2006, Tunnel tests span 35 years of Nevada Test Site history: accessed May 2005 at URL http://www.nv.doe.gov/library/publications/newsviews/ tunnel.htm.

U.S. Geological Survey, 2004, User's manual for the National Water Information System of the U.S. Geological Survey: Ground-Water Site-Inventory System: U.S. Geological Survey Open-File Report 2004-1238, version 4.3, 275 p. 


\section{Appendix 1. Water-Level Database for Rainier Mesa and Vicinity, Nevada Test Site, Nye County, Nevada, 1957-2005}

The database distributed with this report is in Microsoft $\AA$ Access 2000 format. It contains 14 tables with hydrologic information for 54 sites in the Rainier Mesa area. The tables include information on water-level sites, well construction, borehole lithology, aquifers, and water levels. Descriptions of the types of information in the database tables are stored in the database in the table field_descriptions. A general description of each table can be read in the Access project window by opening the database, selecting "view," and then selecting "details." Descriptions of each table column can be made to appear at the bottom of the database window screen by opening a table and moving the cursor to the column of interest.

A Microsoft ${ }^{\circledR}$ Excel workbook also is distributed with this report as an interface to the water-level database. Most of the water-level information from the database is provided in the spreadsheet. Different hydrographs from the Rainier Mesa area can be selected using Excel's built-in AutoFilter. 
This page intentionally left blank. 
For more information concerning the research in this report, contact Director, Nevada Water Science Center

U.S. Geological Survey

2730 N. Deer Run Road

Carson City, Nevada 89701

http://nevada.usgs.gov/ 


$$
\text { 总 }
$$

$\frac{\text { 끌 }}{\frac{\Phi}{ㅇ ㅡ ㅁ ~}}$

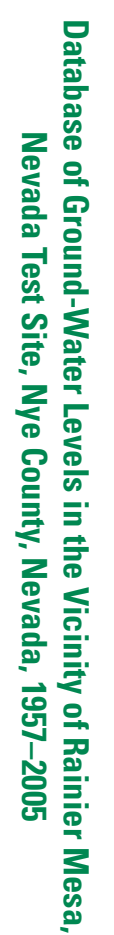

